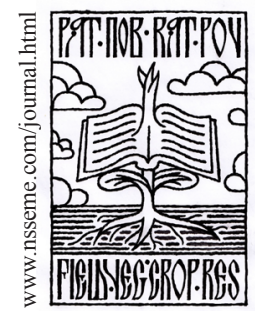

\title{
Production of Yellow Gentian (Gentiana lutea L.) Nursery Plants Suitable for Transplanting and Cultivation under Dry Farming Conditions in Mountain Region of Serbia
}

\author{
Dragoja Radanović • Tatjana Marković • Svetlana Antić Mladenović
}

\author{
received: 10 October 2013, accepted: 27 November 2013 \\ published online: 7 February 2014 \\ (c) 2013 IFVC \\ doi: $10.5937 /$ ratpov50-4635
}

\begin{abstract}
Summary: This paper deals with development of yellow gentian nursery plants in the open winter beds established in the mountainous region of Serbia at $1000 \mathrm{~m}$ a.s.l. Number, weight and size of one-, two- and three-year-old nursery plants were measured in succession for two years. The oneyear-old nursery plants had an average $1.5 \mathrm{~g}$ fresh weight and $0.4 \mathrm{~g}$ dry weight, while the average length and width of the thickened root parts were $6.0 \mathrm{~cm}$ and $0.4 \mathrm{~cm}$, respectively. The average fresh and dry root weights of the two-year-old nursery plants were $4.9 \mathrm{~g}$ and $1.4 \mathrm{~g}$, respectively, with the length and width of the thickened root part $10.8 \mathrm{~cm}$ and $1.2 \mathrm{~cm}$, respectively. The average root weights of the three-year-old plantlets were $15.6 \mathrm{~g}$ (fresh weight) and $4.7 \mathrm{~g}$ (dry weight), but they were too branchy and difficult for transplanting into the field. The average number of yellow gentian nursery plants per $\mathrm{m} 2$ of the open winter bed, following the first, second and third growing year were 714, 243 and 95, respectively. Two-year-old nursery plants proved to be the most suitable for establishing large-scale plantations for the production of yellow gentian root under dry farming conditions in the mountains of Serbia.
\end{abstract}

Keywords: cultivation, Gentiana lutea, mountain region of Serbia, nursery plants, roots, yellow gentian

\section{Introduction}

Yellow gentian (Gentiana lutea L.) is a medicinal plant widely used in folk medicine, pharmaceutical and food industries. Market demands good quality homogenized raw material, Gentianae radix, continuously grow. The content of biologically active compounds defining its quality depends on the growing conditions, plant age and ecotype, among other things (Schultze \& Franz 1980), thus favouring cultivation of this endangered plant species in comparison to its collection from the wild.

Investigations regarding yellow gentian cultivation were initiated few decades ago in France and Germany (Barralis \& Chadoeuf

D. Radanović • T. Marković* •

Institute for Medicinal Plant Research "Dr Josif Pančić, Tadeuša Košćuška 1, 11000 Belgrade, Serbia

e-mail: tmarkovic@mocbilja.rs

S. Antić Mladenović

University of Belgrade, Faculty of Agriculture, Nemanjina 6, 11080 Belgrade-Zemun, Serbia
1973, Franz \& Fritz 1978). Very early, it also started in Romania (Heltmann 1968, 1970) and later in Italy, Finland, and the Balkans (Bezzi et al. 1986, 1996, 1997, Bezzi \& Aiello 1993, Menghini et al. 1996, Galambsi 1996, Kušar \& Baričević 2006, Radanović et al. 2007a, b and 2008). Although more than four decades passed since the first promotion of yellow gentian cultivation technology, its production never really reached massive expansion. The long lasting production of $G$. lutea roots, its slow growth, frequent weed control measures and full crop density maintenance in the early years are the main reasons why farmers are reluctant to cultivate this species.

After the failure of establishing yellow gentian plantations by direct sowing seeds in the field (Barralis et al. 1978), German researchers Franz \& Fitz (1978) developed a successful method

Acknowledgements:

The authors are grateful to the Ministry of Education, Science and Technological Development of the Republic of Serbia for financial support (Grants № TR 31072 and III 46008). 
which includes breaking of the seed dormancy by stratification procedure and further production of nursery plants in the greenhouse conditions. In addition to this method, Fitz et al. (1980) presented similar results regarding the initiation of yellow gentian seed germination by the use of gibberellic acid and later planting 2- or 3-monthold plantlets in the field during the same spring season. This method gave quite good early results in Germany, France and to a certain extent in Italy and Finland (Seitz et al. 2005, Aiello \& Bezzi 1998, Galambosi \& Galambosi 2010). However, the authors reported problems with loss of crop density following the first winter, due to the frost which pulled out a great number of plantlets from the soil (Fritz et al. 1993, Schultze \& Franz 1980, Bezzi \& Aiello 1993). The quality of produced nursery plants is the key issue in achieving a good reception of nursery plants following transplantation and preserving original crop density in plantations.

Production technology for yellow gentian nursery plants in the open winter beds was developed for agro-ecological conditions of Serbian mountains and promoted six years ago (Radanović et al. 2007a). The method is based on seed stratification under the influence of winter temperatures in the natural conditions of the mountain areas and is very easy to use; it requires no special equipment and can be conducted with a small financial investment. Its use initiated the establishment of yellow gentian plantations at several localities in Serbia. However, in practice, utilization of one-yearold nursery plants for these purposes revealed some weak points; the small mass and size of such young nursery plants were the main reason for failures recorded in plantations established under dry farming conditions, common for the majority of Serbian mountain localities above $1000 \mathrm{~m}$ a.s.l. Transplanted one-year-old nursery plantlets were so small and delicate, that they failed to survive the conditions of relatively low rainfall accompanied with frequent occurrence of summer temperatures above $30^{\circ} \mathrm{C}$. In addition, efficient irrigation was impossible at most localities above $1000 \mathrm{~m}$ a.s.l. Overcoming the presented obstacles was the main issue in establishing yellow gentian large-scale cultivation suitable for dry farming conditions. The use of nursery plants older than one year has been considered a possible solution to the problem.

Therefore, the aim of this paper was to examine the characteristics of yellow gentian nursery plants when left in the open winter beds for two or three growing seasons, as the basis for recommendation of an optimal period for their transplantation under the dry farming conditions on arable land in Serbian mountain regions and similar localities in the wider Central Balkan region.

\section{Materials and Methods}

\section{Origin of Plant Material}

Seeds of Gentiana lutea ssp. symphyandra were originally collected from the natural stands of mountain Suvobor $\left(760 \mathrm{~m}\right.$ a.s.l., g. latitude $\mathrm{N} 44^{\circ}$ $08^{\prime} 10^{\prime \prime}$ and g. longitude E $20^{\circ} 11^{\prime} 07^{\prime \prime}$ ) in Serbia, and multiplied since 2002 in experimental small plantations in the forest tree nursery Kaluderske bare of the National Park Tara in Serbia, until used for production of nursery plants in this trial.

\section{Experimental Locality}

The research was conducted in the forest tree nursery Kaluđerske bare of the National Park Tara in Serbia (1004 m a. s. l., g. latitude N $43^{\circ}$ $53^{\prime} 41^{\prime \prime}$ and g. longitude E $\left.19^{\circ} 33^{\prime} 41^{\prime \prime}\right)$, where the

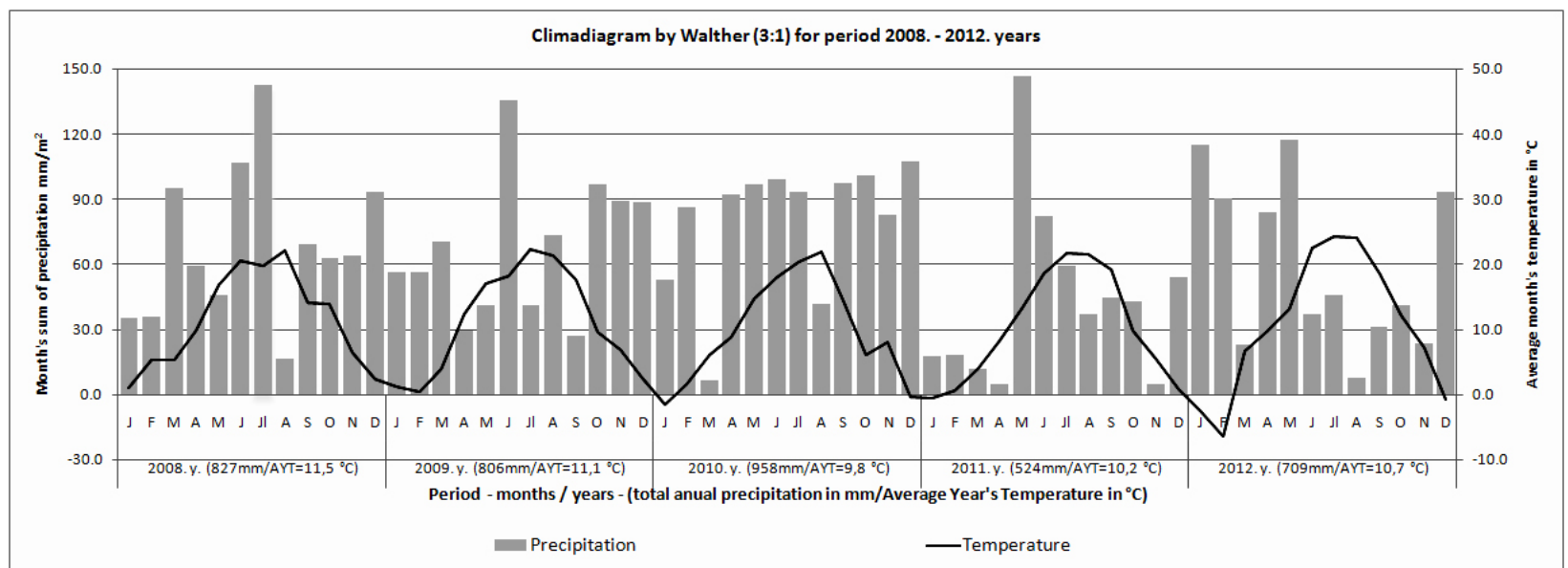

Diagram 1. Rainfalls and temperatures during experimental period (2008-2012) in the forest tree nursery Kaluđerske bare of the National Park Tara, Serbia 
yellow gentian nursery plants have commercially been produced since 2007 .

The main climatic conditions of the experimental locality were as follows: annual temperature was $6.1^{\circ} \mathrm{C}$ and precipitation was 900 $\mathrm{mm}$, while average temperature for the growing season (April-September) was $11.9^{\circ} \mathrm{C}$ and precipitation $448 \mathrm{~mm}$. Rainfalls and temperatures during the experimental period are presented in Diagram 1.

\section{Establishing and Maintaining Open Winter Beds}

The survey was conducted in open winter beds established successively every fall in 2008, 2009, 2010, and 2011 according to the technology of yellow gentian nursery plants production developed by Radanović et al. (2007a).

Open winter beds were established at the cambisol soil type. The composite soil samples were previously collected and analysed using the standard methods for soil chemical analyses (Džamić et al. 1996) in order to ensure similar soil fertility for the beds. The soil used for the open beds preparation were slightly acidic, with high humus/total nitrogen content, well supplied with the plant available potassium, and moderately supplied with plant available phosphorus (Table 1).

The open winter beds were established close to each other, prepared in the same manner, and sown each year in November. The beds were set to be one meter wide, and the seeds were sown in rows $15 \mathrm{~cm}$ apart from each other, applying the sowing rate of $4 \mathrm{~g} / \mathrm{m}^{2}$. During the bed preparation, $6 \mathrm{~kg} / \mathrm{m}^{2}$ of FYM and $100 \mathrm{~g} / \mathrm{m}^{2}$ of NPK 15-1515 were applied, and no additional fertilization was performed until the end of the experimental period. Weed controls were performed manually, the beds were irrigated only in extremely dry periods, and on sunny days they were shaded with low-mounted nets (reducing insolation by $30 \%$ ). During the entire experimental period there was no need for fungicide or insecticide application.

\section{Monitoring of the Nursery Plants}

Measurements regarding the growth and development of nursery plants were carried out following their first, second and third growing seasons in the open winter beds, according to the main scheme presented in Table 2.

During the growing periods in 2011 and 2012, the following periodical measurements were performed on nursery plants:

- In May: assessing the plant density by counting plants;

- In July: measuring fresh and dry weights of the aboveground and underground plant parts. Drying of fresh plant material was conducted in the oven at temperatures up to $65^{\circ} \mathrm{C}$;

- In October (at the end of the growing season): assessing the plant density by counting plants; weighing fresh and dry underground plant parts; measuring the diameter of the primary root in the first centimetre of the root head; measuring the total length of root (together with root branches); measuring the length of the thickened section of the primary root and counting the number of lateral roots (only in older nursery plants).

All measurements were conducted on samples (nursery plants of different ages) randomly taken from the open beds. The samples consisted of

Table 1. Basic chemical properties of two average soil samples $(0-30 \mathrm{~cm})$ from the open beds

\begin{tabular}{ccccccc}
\hline Sample & \multicolumn{1}{c}{$\begin{array}{c}\text { HH } \\
\text { in } \mathrm{H}_{2} \mathrm{O}\end{array}$} & $\begin{array}{l}\text { in } \\
\mathrm{KCl}\end{array}$ & $\begin{array}{c}\text { Tumus } \\
\%\end{array}$ & $\begin{array}{c}\text { Total } \\
\%\end{array}$ & $\begin{array}{c}\mathrm{AL}-\mathrm{P}_{2} \mathrm{O}_{5} \\
\mathrm{mg} / 100 \mathrm{~g}\end{array}$ & $\begin{array}{c}\mathrm{AL}-\mathrm{K}_{2} \mathrm{O} \\
\mathrm{mg} / 100 \mathrm{~g}\end{array}$ \\
\cline { 2 - 7 } 1 & 6.61 & 5.59 & 5.37 & 0.34 & 13.83 & 21.67 \\
2 & 6.69 & 5.71 & 5.45 & 0.34 & 12.30 & 18.93 \\
\hline
\end{tabular}

Table 2. The scheme of monitoring the growth and development of yellow gentian nursery plants in the open winter beds established in four successive years (2009-2012)

\begin{tabular}{lcc|cc}
\hline \multirow{2}{*}{$\begin{array}{l}\text { Open beds } \\
\text { establishment }\end{array}$} & \multicolumn{4}{c}{ Nursery plants monitoring } \\
\cline { 2 - 5 } & 2009 & 2010 & \multicolumn{2}{c}{ Morphological measurements } \\
\hline Fall 2008 & I growing season & II growing season & III growing season & 2012 \\
Fall 2009 & - & I growing season & II growing season & III growing season \\
Fall 2010 & - & - & I growing season & II growing season \\
Fall 2011 & - & - & - & I growing season \\
\hline
\end{tabular}


sequences of the same row lengths, taken in four replications, from the middle of corresponding open bed; the row length for one-year-old nursery plants was $30 \mathrm{~cm}$, and $80 \mathrm{~cm}$ for the two- and three-year-old nursery plants.

The obtained data were statistically analysed whether by the use of descriptive statistics or by ANOVA program with the implementation of the LSD-test.

\section{Results and Discussion}

\section{Growth and Development of Nursery Plants of Different Ages}

The average fresh and dry weight of the underground parts of one-, two- and three-yearold yellow gentian nursery plants observed at the end of two vegetations (2011 and 2012), as well as calculated percentage differences in the corresponding average weights (both fresh and dry) between the years are presented in Table 3 .

As shown in Table 3, the highest differences between the years 2011 and 2012 in both fresh and dry average root weight were observed in oneyear-old nursery plants; in 2012 they were higher by $47.9 \%$ and $36.1 \%$, respectively. Similar trend was observed for the root weight of the two- and three-year-old nursery plants in 2012, although the weight increase was lower (Table 3). The higher root weight of nursery plants of all ages, observed by the end of 2012, probably resulted from more favourable climatic conditions of that year in comparison to 2011 (Diagram 1). Climatic differences between the years were particularly obvious during the winter-spring period. In 2012, the amount of precipitation for the period January-April was higher by $260 \mathrm{~mm} / \mathrm{m}^{2}$, and the average temperature for March-April (beginning of growing season) was higher by $2.2^{\circ} \mathrm{C}$ (Diagram 1). Such conditions in 2012 positively affected the initial growth of gentian nursery plants in April which resulted in greater root weight of plantlets of all ages observed by the end of that growing season, but most obviously in the case of oneyear-olds (Table 3 ).

As expected, during three years of growth in open winter beds, the average weight of underground parts of gentian plantlets increased significantly. The dry root weight of one-year-old plantlets obtained by the end of the first growing period of 2011 and 2012 increased 3.0 to 3.8 times, respectively in the second vegetation, and 10.1 to 12.4 times in the third one, respectively. In addition, the average dry root weights of nursery plants at the end of third vegetation were 3.3 times higher in both years in comparison to those of the second one (Table 3).

Due to reduced spacing, nursery plants in the open beds achieved significantly lower root weight than the same age nursery plants transplanted in the field. Franz \& Fritz (1978) reported that weight of fresh gentian root obtained in Bavaria ranged from 1.7 to $3.3 \mathrm{~g}$ for one-year-old yellow gentian plantlets, 22-43 $\mathrm{g}$ for two-year-olds, and 93-121 g for three-year-olds. In our previous experiments conducted in the same environmental conditions, average weight of fresh roots following the second and the third growing periods in the field were $11.8 \pm 3.9$ $\mathrm{g}$ and $77 \pm 26.1 \mathrm{~g}$, respectively (Radanović et al. 2007b). Based on these observations, it seems illogical to grow nursery plants in open beds for two years in order to achieve such low mass (Table 3), as the plantlets transplanted in the field reach several times higher weight and size in the same period of time. However, there are many evidences of one-year-old plantlets decay in the field and dramatically smaller number of surviving and persisting plants in the successive growing seasons in the mountains of the Balkans and the Apennines (Bezzi et al. 1997, Kušar \& Baričević 2007). Consequently, this may justify the investment in keeping nursery plants in the open beds for two years under the dry farming

Table 3. Average weight of the underground parts of yellow gentian nursery plants of different age, recorded at the end of two vegetations (in October)

\begin{tabular}{llll|lll}
\hline \multirow{2}{*}{$\begin{array}{l}\text { The age of } \\
\text { nursery plants }\end{array}$} & \multicolumn{2}{c}{ Average weights of the underground nursery plant parts } \\
\cline { 2 - 7 } & \multicolumn{3}{c}{ Fresh weight $(\mathrm{g})$} & \multicolumn{3}{c}{ Dry weight $(\mathrm{g})$} \\
\cline { 2 - 7 } & 2011 & 2012 & $\begin{array}{l}\text { Ratio }(\%) \\
2012 / 2011\end{array}$ & 2011 & 2012 & $\begin{array}{l}\text { Ratio }(\%) \\
2012 / 2011\end{array}$ \\
\hline One year old & 1.21 & 1.79 & $147.93 \%$ & 0.36 & 0.49 & $136.11 \%$ \\
\hline Two year old & 4.69 & 5.09 & $108.53 \%$ & 1.36 & 1.49 & $109.56 \%$ \\
\hline Three year old & 14.28 & 16.95 & $118.70 \%$ & 4.45 & 4.94 & $111.01 \%$ \\
\hline LSD 5\% & 1.26 & 1.57 & & 0.30 & 0.50 & \\
LSD 1\% & 1.81 & 2.26 & 0.43 & 0.72 & \\
\hline
\end{tabular}


Table 4. The average length and diameter of the underground parts of yellow gentian nursery plants of different age, observed at the end of two growing seasons (in October)

\begin{tabular}{lcccc}
\hline \multirow{2}{*}{$\begin{array}{l}\text { The age of } \\
\text { nursery plants }\end{array}$} & $\begin{array}{c}\text { Root collar diameter } \\
(\mathrm{mm})\end{array}$ & $\begin{array}{c}\text { Primary root length* } \\
(\mathrm{cm})\end{array}$ & $\begin{array}{c}\text { Root collar diameter } \\
(\mathrm{mm})\end{array}$ & $\begin{array}{c}\text { Primary root length* } \\
(\mathrm{cm})\end{array}$ \\
\hline One-year old & 4.18 & 5.58 & 4.48 & 6.33 \\
Two-year old & 10.68 & 10.80 & 13.03 & 10.75 \\
Three-year old & 16.00 & 16.30 & 17.40 & 17.48 \\
\hline LSD 5\% & 1.50 & 1.42 & 2.31 & 1.69 \\
LSD 1\% & 2.16 & 2.03 & 3.32 & 2.43 \\
\hline
\end{tabular}

* Refers to the thickened primary root part

Table 5. Number of yellow gentian nursery plants of different age in the open winter beds at the beginning of the growing period (mid-May) and at the end (late September) in 2012

\begin{tabular}{|c|c|c|c|c|c|c|}
\hline \multirow{2}{*}{$\begin{array}{l}\text { Yellow gentian } \\
\text { nursery plants }\end{array}$} & \multicolumn{3}{|c|}{14 May 2012} & \multicolumn{3}{|c|}{24 September 2012} \\
\hline & $\begin{array}{c}\text { One year } \\
\text { old }\end{array}$ & $\begin{array}{c}\text { Two year } \\
\text { old }\end{array}$ & $\begin{array}{c}\text { Three year } \\
\text { old }\end{array}$ & $\begin{array}{c}\text { One year } \\
\text { old }\end{array}$ & $\begin{array}{c}\text { Two year } \\
\text { old }\end{array}$ & $\begin{array}{c}\text { Three year } \\
\text { old }\end{array}$ \\
\hline $\begin{array}{l}\text { Average number } \\
\text { per } \mathrm{m}^{2}\end{array}$ & 1616.7 & 386.7 & 138.0 & 714.0 & 243.3 & 95.3 \\
\hline Min & 1347 & 267 & 73 & 560 & 180 & 67 \\
\hline $\operatorname{Max}$ & 2020 & 567 & 273 & 900 & 373 & 147 \\
\hline St. dev. & 237.0 & 119.7 & 57.1 & 102.3 & 66.5 & 27.6 \\
\hline
\end{tabular}

conditions, especially if that would preserve the crop density in the following growing seasons.

The average lengths of the thickened part of the primary yellow gentian root and the root collar diameter in the first centimetre of its length given in Table 4 illustrate differences in sizes of the underground nursery plant parts of the same age between different growing seasons. Root diameters of the nursery plants of the same age were in most cases similar in both years; the biggest difference in root collar diameter between the years was $22.0 \%$ for two-year-old nursery plants, while the differences were smaller for one- and three-yearold ones, $7.2 \%$ and $8.8 \%$, respectively. As for the length of the thickened primary root part, the biggest difference was observed in one-year-old plants $(13.4 \%)$, and a bit smaller $(7.2 \%)$ in threeyear-old ones, while the length of thickened root of the two-year-old nursery plants was virtually identical in both years (Table 4). The larger root collar diameter and slightly larger primary root length observed in 2012 may be associated with more favourable temperature/precipitation regime in the first part of 2012 growing season compared to those of 2011 (Diagram 1).

Root collar diameters at the end of the second and the third growing season were on average 2.8 and 3.9 times higher, respectively, than those at the end of the first growing season. The length of the thickened part of the primary root following the second growing season was approximately 1.8 times higher, and following the third growing season it was 2.8 times higher than those achieved at the end of the first growing season. In comparison to the two-year-old nursery plants, the three-year-old ones increased their root collar diameter and their root length 1.4 times and 1.6 times on average, respectively.

As it was expected, the root weight and sizes were multiplied when the one-year-old nursery plants were left to grow in the open beds for more than one growing season; the increase of weight was much higher than the increase of the lengths and the root collar diameters (Tables 3 and 4). However, these increases brought about reduction in the number of nursery plants per unit of area (Table 5).

Since yellow gentian seed germination rates prove not to be uniform each year, depending mainly on climatic factors during its formation and ripening (Radanović et al., 2005), a relatively high sowing rate (3-5 g of natural seeds per $\mathrm{m}^{2}$ ) has to be applied in order to provide a sufficient number of seedlings (1.616 seedlings per $\mathrm{m}^{2}$ ) in the open beds. Because delicate gentian plantlets are sensitive to unfavourable environmental conditions (high insolation and temperatures) in the early stages during their first growing season in the beds significant reduction in density of plantlets occurred; at the end of the first growing 
season, the number of nursery plantlets was several times lower than the number of seedlings (Table 5). Following their second and third growing seasons in the open beds, this number reduced even more by the end of the growing season (to 243.3 per $\mathrm{m}^{2}$ and 95.3 per $\mathrm{m}^{2}$, respectively) due to freezing in winter or competition in which plantlets with bigger habitus suppressed the less developed ones until those eventually weakened and died (Table 5). At this point it is reasonable to ask whether the lower density of plantlets in the seedlings phase would have a positive effect on the number and size of gentian nursery plants during the threeyear period spent in the open beds.

\section{Development of Nursery Plants during Three Growing} Seasons in the Open Winter Beds

Depending on the weather conditions in the first growing period yellow gentian seedlings were emerging from late March and during April, while the primary radical reached of $3-7 \mathrm{~cm}$ in length in late April and early May. Variation range of the underground plant parts weight was very wide (Table 6 ), as a consequence of uneven seedlings growth and development, and their uneven density in the open bed rows. Therefore, at the end of the first growing season only $34.6 \%$ of the young nursery plants reached the fresh weight of the underground parts above $2 \mathrm{~g}$ (Table 6). In addition, their average root thickness was $\sim 0.45 \mathrm{~cm}$ at that time and the average length of the fleshy (thickened) primary root was $6.33 \mathrm{~cm}$ (Table 6 and Photo 1). Consequently, plantlets of such weight and size are not always capable of surviving unfavourable conditions after being transplanted into field, thus severe drying of their mass occurs in dry farming conditions in the mountainous areas of Serbia, mostly as a consequence of insufficient soil moisture and often high temperatures during the period JuneAugust. According to our experiences, in such circumstances only larger nursery plants were able to survive. Similar problems of losing the planted seedlings and the inability to achieve a sufficient number of plants in gentian plantations due to unfavourable climatic conditions were also observed in other countries, namely in Italy (Bezzi \& Aiello 1993, Bezzi et al. 1997) and Slovenia (Kušar \& Baričević 2007).

In the second growing period, up to the middle of growing season (July), nursery plants significantly increased the size and weight of their underground parts, at the same time considerably increasing the leaf rosette (Table 6 and Photo 2). Weight of their aboveground parts in this period accounted to approximately $50 \%$ of their underground parts weight. The average total weigth of the fresh and dry plantlets were $4.44 \mathrm{~g}$ and $1.16 \mathrm{~g}$, respectively, though interval of variation was very wide (Table 6). Unlike the open winter beds, gentian plantlets of the same age growing in the field in the middle of the second growing period achieved much higher weight and had an almost equal ratio of their fresh weight of the underground and the aboveground parts; $11.8 \mathrm{~g}$ root and $10.15 \mathrm{~g}$ leaf rosette (Radanović et al. 2007b). It is obvious that the reduced spacing between nursery plants in the open beds, compared to large scale plantation condition, considerably decreased root growth and affected the aerial plant parts in particular.

The average values of fresh and dry weights, root collar diameter, length of the thickened primary root part, and total root length reached at the end of the second season, made twoyear-old nursery plantlets much stronger in comparison to the one-year-old ones (Table 6, Photos 1 and 2). About $80 \%$ of nursery plants had fresh underground part weigth over $2 \mathrm{~g}$, while $65.6 \%$ of them had dry root weight over $1 \mathrm{~g}$ (Table 6). Based on the obtained data, it can be assumed that $2 / 3$ of the two-year-old nursery plants produced in the open winter beds might be suitable for establishing plantations in dry farming conditions of the mountainous areas of Serbia. The only disadvantage of their biennial growing in the open beds may be an increase in lateral branching of the primary root compared to the one-year-old nursery plants (Photos 1 and 2), though the lateral roots were quite thin and usually do not represent a great problem if appropriate planting method is applied.

In the third growing period, very wide interval of variation of the weight parameters was observed, similarly to the younger yellow gentian nursery plants (Table 6); the average fresh and dry weight of the underground parts were $17 \mathrm{~g}$ and $5 \mathrm{~g}$, respectively. The average thickness of the root collar was $16.3 \mathrm{~mm}$, and the primary root become significantly branched with 2-5 thickened lateral roots greatly differing in length (4-22 $\mathrm{cm}$ ) (Table 6), which made them quite robust. According to their weight, almost all three-yearold nursery plants were considered acceptable for transplantation under dry farming conditions, but the vast ramification of their roots reduced their quality in terms of practical suitability in establishing plantations for yellow gentian root production. Therefore, such nursery plants might be preferentially used for returning yellow gentian to its natural habitats where this species is eradicated due to its excessive exploitation. 
Table 6. Size and weight of the underground parts of one-, two- and three-year-old yellow gentian nursery plants, by the end of the growing season in October 2012

\begin{tabular}{|c|c|c|c|c|c|c|c|}
\hline \multirow[t]{2}{*}{ Observed properties } & \multirow[t]{2}{*}{ Mean } & \multirow[t]{2}{*}{ Min. } & \multirow[t]{2}{*}{ Max. } & \multirow[t]{2}{*}{$\begin{array}{l}\text { Std. } \\
\text { Dev. }\end{array}$} & \multicolumn{3}{|c|}{$\begin{array}{l}\text { Contribution of plantlets of } \\
\text { different root weights per } \\
\mathrm{m}^{2} \text { of the open beds (\%) }\end{array}$} \\
\hline & & & & & $>2 \mathrm{~g}$ & $1-2 \mathrm{~g}$ & $<1 \mathrm{~g}$ \\
\hline \multicolumn{8}{|c|}{ One-year-old nursery plants at the end of October } \\
\hline Weight of dry underground parts (g) & 0.49 & 0.15 & 0.80 & 0.180 & 0.0 & 0.0 & 100.0 \\
\hline Weight of fresh underground parts (g) & 1.79 & 0.60 & 3.00 & 0.643 & 34.6 & 50.4 & 15.0 \\
\hline Root collar diameter (mm) & 4.48 & 2.00 & 10.00 & 1.914 & & & \\
\hline Thickened primary root length $(\mathrm{cm})$ & 6.33 & 2.50 & 14.00 & 2.728 & & & \\
\hline Total root length $(\mathrm{cm})$ & 11.52 & 4.50 & 18.00 & 3.575 & & & \\
\hline \multicolumn{8}{|c|}{ Two-year-old nursery plants in mid-july } \\
\hline Weight of fresh aboveground parts (g) & 1.52 & 0.20 & 4.50 & 1.215 & 20.2 & 34.7 & 45.1 \\
\hline Weight of fresh underground parts (g) & 2.92 & 0.55 & 7.40 & 2.114 & 65.1 & 20.2 & 14.7 \\
\hline Weight of dry aboveground parts (g) & 0.35 & 0.04 & 1.00 & 0.280 & 0.0 & 5.3 & 94.7 \\
\hline Weight of dry underground parts (g) & 0.81 & 0.15 & 2.10 & 0.594 & 10.4 & 30.1 & 59.5 \\
\hline \multicolumn{8}{|c|}{ Two-year-old nursery plants at the end of October } \\
\hline Weight of fresh underground parts $(\mathrm{g})$ & 5.09 & 0.50 & 16.50 & 4.342 & 80.3 & 14.7 & 5.0 \\
\hline Weight of dry underground parts (g) & 1.49 & 0.15 & 4.80 & 1.263 & 40.1 & 25.4 & 34.5 \\
\hline Root collar diameter $(\mathrm{mm})$ & 13.03 & 10.00 & 17.00 & 2.757 & & & \\
\hline Thickened primary root length $(\mathrm{cm})$ & 10.75 & 6.00 & 16.00 & 3.489 & & & \\
\hline Total root length $(\mathrm{cm})$ & 18.33 & 15.00 & 21.00 & 2.658 & & & \\
\hline \multicolumn{8}{|c|}{ Three-year-old nursery plants in mid-July } \\
\hline Weight of fresh aboveground parts (g) & 6.66 & 1.80 & 27.10 & 6.710 & 86.7 & 13.3 & 0.0 \\
\hline Weight of fresh underground parts (g) & 15.51 & 4.40 & 52.50 & 12.994 & 100.0 & 0.0 & 0.0 \\
\hline Weight of dry aboveground parts (g) & 1.59 & 0.45 & 6.60 & 1.625 & 20.0 & 33.3 & 46.7 \\
\hline Weight of dry underground parts (g) & 4.24 & 1.20 & 15.00 & 3.668 & 73.3 & 26.7 & 0.0 \\
\hline \multicolumn{8}{|c|}{ Three-year-old nursery plants at the end of October } \\
\hline Weight of fresh underground parts (g) & 16.97 & 2.00 & 44.50 & 13.305 & 100.0 & 0.0 & 0.0 \\
\hline Weight of dry underground parts (g) & 4.96 & 0.60 & 13.00 & 3.860 & 82.0 & 17.3 & 2.7 \\
\hline Root collar diameter (mm) & 16.3 & 13,00 & 21,00 & 0.281 & & & \\
\hline Thickened primary root length $(\mathrm{cm})$ & 6.58 & 4.00 & 9.00 & 1.960 & & & \\
\hline Total root length $(\mathrm{cm})$ & 18.83 & 17.00 & 22.00 & 1.941 & & & \\
\hline $\begin{array}{l}\text { Number of lateral root branches }(\geq 35 \% \text { of } \\
\text { the primary root thickness) }\end{array}$ & 4.00 & 2.00 & 5.00 & 1.265 & & & \\
\hline
\end{tabular}




\section{Conclusions}

Based on the presented quality parameters of $G$. lutea nursery plants, production procedure of two-year-old nursery plants in the open winter beds might be recommended. In the mountainous regions of Serbia, at altitudes above $1000 \mathrm{~m}$, approximately 195 high quality G. lutea nursery plants per square meter of the open winter beds can be produced in the two-year production period with fresh roots weight of over $2 \mathrm{~g}$. The root branching depends on seedlings density in the open beds; lateral root branches, on average one or two, are thin and do not represent a problem during field transplantation. Application of such nursery plants might significantly increase percentage of their reception in the field; therefore, greater success in preserving the crop density of the established yellow gentian plantations might be achieved in the mountainous region of Serbia and the Balkans.

\section{References}

Aiello, N., \& Bezzi A. (1998). Genziana maggiore (Gentiana lutea L.): Aspettibiologici, qualitattivi e produttivi. Agricolturaricerca, 176, 8-17.

Barralis, G., \& Chadoeuf R. (1973). La germination des graines de Gentiana lutea L. Bull. Acad. Agric. Fr. 79.

Barralis, G., Chadoeuf, R., \& Desmarest, P. (1978). New trends of Gentiana lutea cultivation. Acta Horticulturae, 73, 303-306.

Bezzi, A., Aiello, N., \& Tartaroti M. (1986). La coltivazione di Gentiana lutea L. in ambienti montani. Agricoltura Ricerca, 62, 67-72.

Bezzi, A. \& Aiello, N. (1993). The cultivation of Yelow Gentian (Gentiana lutea L.) on the pre-Alps and Apenninic Mountains: Results and Aplications. WOCMAP I - Medicinal and Aromatic Plants Conference: part 3 of 4. Acta Horticulturae, $331,19-25$.

Bezzi, A., Vender, C., \& Scartezzini, F. (1996). Datimorfologici e produttivi rilevati su coltivazioni di Gentiana lutea L. (19811994). In: Genziana e specie amaro-aromatiche. Ricerche ed Applicazioni. Proceedings, Camerino, 8-10 June 1995, pp. 3556. Edited by C.I.A.S., Università di Camerino.

Bezzi, A., Vender, C., \& Aiello, N. (1997). Coltivazione di ecotipi di Gentiana lutea L. ottenuti da semeraccolto da piante coltiva-

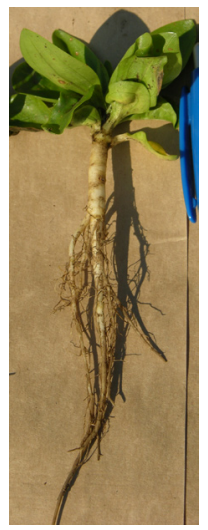

Photo 1.

One-year-old gentian nursery plants in

October 2012
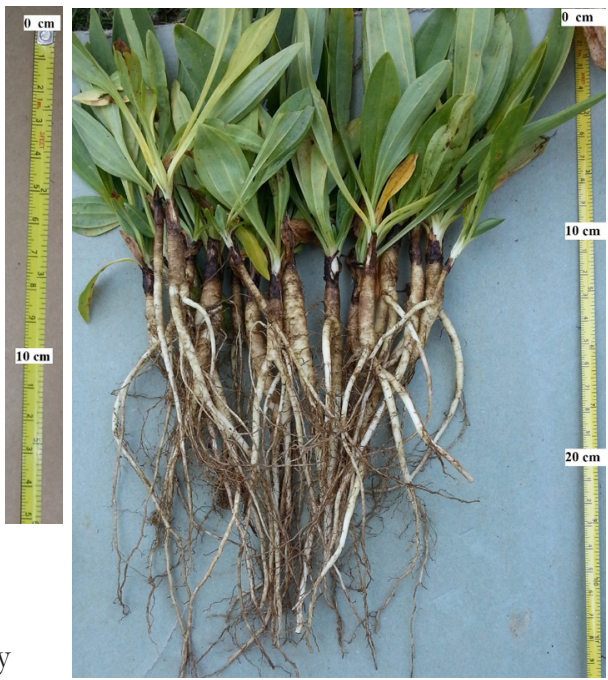

Photo 2. Two-year-old gentian nursery plants in mid-July 2012

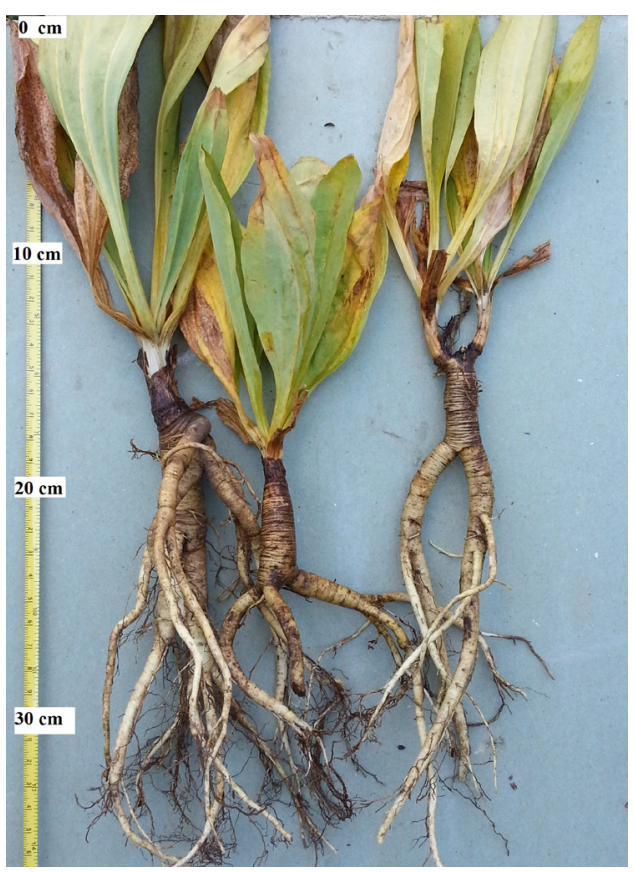

Photo 3. Three-year-old gentian nursery plants in mid-July 2012 
te e spontanee. ISAFA Comunicazioni di ricerca, 96, 3: 20-23.

Džamić, R., Stevanović, D., \& Jakovljević, M. (1996). Praktikum iz agrohemije. Poljoprivredni fakultet, Beograd, pp 162.

Franz, Ch., \& Fritz, D. (1978). Cultivation aspects of Gentiana lutea L. Acta Horticulturae, 73, 307-314.

Fritz, D., Franz, C., \& Kretschmer, M. (1980). Keimung, Saatgutlagerung und Jung pflanzen anzucht von gelben Enzian (Germination, seed storage and seedling production of yellow gentian). Deutscher Gartenbau, 34, 1350-1353.

Fritz, D., Bezzi, A., \& Marocke, R. (1993). Cultivation of Gentiana lutea L. in marginal arable areas (e.g. hilly upland regions). Results of the AGRIMED working group (1986-1988) „Gentiana lutea“, In: G. Marshall and K. Svoboda (eds.), The Production and Impact of Special Minor Crops in the Rural Community. Proceedings of a workshop in the CEC programme, held in Brussels on April 27-28, 1993. p. 129-139.

Galambosi, B. (1996). Experiences of cultivation Gentiana lutea L. in Finland. In: Attidel Convegno Genziana e specie amaroaromatiche. Ricerche ed Applicazioni. (Camerino, 8-10 giugno 1995. L'uomo e l'ambiente, 19, pp. 139-142.

Galambosi, B. \& Galambosi, Zs. (2010). Seedling Quality and Seed Yield of Gentiana lutea L. Proc. $4^{\text {th }}$ IS on Breeding Research on Medicinal and Aromatic Plants (ISBMAP 2009) Eds.: Baričevič et al. Acta Horticulturae 860, 255-258.

Heltmann, H. (1968). Contributii la Studiul Biologiei Ghunturiigalbeni (Gentiana lutea L.) in cercari preliminare de introducere in cultura in Tara noastra. Com. de Bot. Roman., 7: 37.

Heltmann, H. (1970). Introducerea in Cultura a Speciei Gentianalutea L. in Romania. Rev. Medical. 16, 389.

Kušar, A., \& Baričevič, D. (2006). Cultivation trials of yellow gentian (Gentiana lutea L. subsp. Symphyandra Murb.) in west part of Slovenia. Acta Agriculturae Slovenica, 87, 213-22.
Menghini, S., Pocceschi, N., \& Matteini, G.M. (1996). Unquinquennio di coltivazion esperimentale di Gentiana lutea L. in provincia di Rieti. In: Genziana e specie amaroaromatiche. Ricerche e Applicazioni. Camerino, 8-10 June 1995. Edited by C.I.A.S., Università di Camerino. pp. 163-166.

Radanović, D., Stepanović, B., \& Nastovski, T. (2005). Some experiences in nursery plants production of Yellow gentian (Gentiana lutea L.) with an accent on its seed dormancy. Contemporary Agriculture, 54, 474-481.

Radanović D., Marković T. \& Spasojević B. (2007a). Beshormonski postupak proizvodnje sadnica žute lincure (Gentiana lutea L.) u otvorenim lejama; Tehničko rešenje; Institut za proučavanje lekovitog bilja „Dr Josif Pančić“ Beograd, str. 1 - 16.

Radanovic, D., Markovic, T. \& Jankovic, T. (2007b). Morphological and chemical parameters of importance for cultivation of Gentiana lutea L. in mountain region of Serbia. $1^{\text {st }}$ Int. Sci. Conf. on Medicinal, Aromatic and Spice Plants. Nitra, Slovakia. Proceedings, 28-32.

Radanovic, D., Markovic, T., Jankovic, T. \& Pljevljakusic, D. (2008). Yield and quality of Yellow gentian (Gentiana lutea L.) root grown in mountaneous region of Serbia. V Conference on Medicinal and Aromatic Plants of Southeast European Countries (V CMAPSEEC), Brno, 2-5.9.2008. Czech Republic. Book of abstracts, 119.

Seitz, R., Lange, D., \& Franz, C. (2005). Gelber Enzian - Porträt Einer Arzneipflanze, Zeitschrift für Phytotherapie, 26, 143 150 .

Schultze, J., \& Franz, Ch. (1980). Sugars, bitter substances and essential oils of Gentiana lutea L. in dependence of ecotype, plant age and stage of development. Acta Horticulturae, 96, 311-315.

\title{
Proizvodnja sadnica žute lincure (Gentiana lutea L.) za rasad i gajenje u uslovima suvog ratarenja u planinama Srbije
}

\author{
Dragoja Radanović • Tatjana Marković • Svetlana Antić Mladenović
}

Sažetak: U radu je prikazan razvoj sadnica žute lincure u rasadniku u otvorenim zimskim lejama zasnovanim u planinskom regionu Srbije na 1000 m nadmorske visine. Meren je broj, masa i veličina sadnica jednogodišnje, dvogodišnje i trogodišnje starosti u sukcesiji tokom dve godine. Sadnice jednogodišnje starosti imale su prosečnu masu $1,5 \mathrm{~g}$ (svežu) odnosno $0,4 \mathrm{~g}$ (suvu) i prosečnu dužinu zadebljalog dela korena $6,0 \mathrm{~cm}$ sa prosečnom debljinom $0,4 \mathrm{~cm}$. Prosečna masa svežeg korena sadnica dvogodišnje starosti je bila 4,9 g a suvog korena 1,4 g uz dužinu zadebljalog dela korena 10,8 cm i debljinu vrata korena $1,2 \mathrm{~cm}$. Prosečne mase korena trogodišnjih sadnica su iznosile 15,6 g (sveža), odnosno 4,7 g (suva), ali je koren ovih sadnica bio previše razgranat i stoga nepodesan za plantažnu sadnju. Prosečan broj dobijenih sadnica po $\mathrm{m} 2$ leje na kraju prve godine je iznosio 714, na kraju druge 243 i treće 95 . Dvogodišnje sadnice žute lincure proizvedene u otvorenim zimskim lejama, po svojim karakteristikama se se pokazale kao najpogodnije za zasnivanju plantaža lincure za proizvodnju korena u uslovima suvog ratarenja u planinama Srbije.

Ključne reči: Gentiana lutea, koren, planinski predeo Srbije, sadnice, uzgajanje, žuta lincura 